\title{
EXPERIMENTAL SUBSTANTIATION OF PERMEABILIZED HEPATOCYTES MODEL FOR INVESTIGATION OF MITOCHONDRIA IN SITU RESPIRATION
}

\author{
V. M. MERLAVSKY, B. O. MANKO, O. V. IKKERT, V. V. MANKO \\ Ivan Franko National University of Lviv, Ukraine; \\ e-mail:vvmanko@Inu.edu.ua
}

To verify experimentally the model of permeabilized hepatocytes, the degree of cell permeability was assessed using trypan blue and polarographycally determined cell respiration rate upon succinate (0.35 $\mathrm{mM})$ and $\alpha$-ketoglutarate $(1 \mathrm{mM})$ oxidation. Oxidative phosphorylation was stimulated by ADP $(750 \mu M)$. Hepatocyte permeabilization depends on digitonin concentraion in medium and on the number of cells in suspension. Thus, the permeabilization of 0.9-1.7 million cells $/ \mathrm{ml}$ was completed by $25 \mu \mathrm{g} / \mathrm{ml}$ of digitonin, permeabilization of 2.0-3.0 million cells $/ \mathrm{ml}$ - by $50 \mu \mathrm{g} / \mathrm{ml}$ of digitonin and permeabilization of 4.0-5.6 million cells $/ \mathrm{ml}$ - by $100 \mu \mathrm{g} / \mathrm{ml}$. Thus, the higher is the suspension density, the higher digitonin concentration is required. Treatment of hepatocytes with digitonin resulted in a decrease of endogenous respiration rate to a minimum upon 20-22 $\mu \mathrm{g}$ of digitonin per 1 million cells. Supplementation of permeabilized hepatocytes with $\alpha$-ketoglutarate maintained stable respiration rate on the level higher than endogenous respiration at the corresponding digitonin concentration, unlike the intact cells. Respiration rate of permeabilized hepatocytes at the simultaneous addition of $\alpha$-ketoglutarate and ADP increased to the level of intact cell respiration, irrespective of digitonin concentration. Addition of solely succinate and especially succinate plus ADP markedly intensified the respiration of permeabilized hepatocytes to the level higher than that of intact cells. The dependence of succinate-stimulated respiration on digitonin concentration reached maximum at 20-22 $\mu \mathrm{g}$ of digitonin per 1 million cells. Optimal ratio of digitonin amount and the cell number in suspension is expected to be different in various tissues.

Key words: permeabilized hepatocytes, digitonin, mitochondria, respiration, succinate, $\alpha$-ketoglutarate.

$\mathrm{T}$ he digitonin-permeabilization of hepatocytes depends on both digitonin concentraion in medium and the number of cells in suspension. Thus, complete permeabilization was observed at cell concentration $0.9-1.7 \times 10^{6}$ cells $/ \mathrm{ml}$ of suspension and digitonin concentration $25 \mu \mathrm{g} / \mathrm{ml}$, or at cell concentration $2.0-3.0 \times 10^{6}$ cells $/ \mathrm{ml}$ and digitonin concentration $50 \mu \mathrm{g} / \mathrm{ml}$, or at cell concentration $4.0-5.6 \times 10^{6}$ cells $/ \mathrm{ml}$ and digitonin concentration $100 \mu \mathrm{g} / \mathrm{ml}$.

The rate of oxygen uptake is one of the integral parameters characterizing the functional state of energy-producing cell system. This rate is measured in a polarographic system using an oxygen electrode. The methodological basis for the study of mitochondrial respiration was suggested by Chance and Williams, 1955 [1]. They characterized the basic metabolic states, in which the electron flow intensity in the respiratory chain is determined by various factors such as: availability of endogenous oxida- tion substrates (state $S_{1}$ ), concentrations of ADP and phosphate required for oxidative phosphorylation (state $S_{2}$ ), the presence of exogenous oxidation substrate at an excess of exogenous ADP (activation of oxidative phosphorylation, state $S_{3}$ ) or ADP depletion (cessation of oxidative phosphorylation, state $S_{4}$ ), low pressure (depletion) of oxygen (state $S_{5}$ ) [1].

Monitoring of respiration rate in the isolated mitochondria suspension contributed to a better understanding and control of the mitochondrial oxidation pathway specifically in these organelles. However, the absence of structural and functional links between isolated mitochondria and other cell components makes it difficult to investigate the regulation of mitochondrial oxidative processes, in which other organelles and cytosolic factors are involved. In the cell, mitochondria are present in close contacts with endoplasmic reticulum and Golgi complex [2-4], and the intensity of oxidative phosphorylation is regulated by adjacent organelles, for example, by the al- 
teration in the cytosol ATP consumption and $\mathrm{Ca}^{2+}$ concentration [3]. Therefore, the study of isolated mitochondria may not fully indicate the peculiarities of their functioning in vivo. Given, the polarographic measurement of oxygen uptake has been adapted for the study of respiration of permeabilized cells (or mitochondria in situ).

This method is applied in various degrees to skeletal muscle fibers [5], smooth muscle cells [6], hepatocytes [7], pancreacytes [8] and enable to maintain the interaction between mitochondrial respiration and other cell processes. The advantage of using permeabilized cells is that, unlike the isolated mitochondrial fraction, entire cell population of mitochondria is studied in its natural environment [9].

Plasma membrane permeabilization is performed for the introduction of exogenous agents that affect the respiratory chain, but normally do not penetrate through membrane [10-12]. Such agents include ions, substrates of the Krebs cycle, regulators of the cycle's enzyme activity, adenine nucleotides, inhibitors of respiratory chain complexes etc.

Digitonin is one of the most effective plasma membrane permeabilizers that form insoluble complexes with cholesterol causing the pore formation [13]. It is believed that digitonin affects plasmalemma selectively without breaking other membrane integrity, since the cholesterol content therein is lower by several orders [14]. It is proved that digitonin at low concentrations $(0.05-0.15 \mathrm{mg} / \mathrm{ml})$ does not cause the disruption of the intracellular organelles and cytoskeleton ultrastructures [15]. However, digitonin at concentrations of $0.8 \mathrm{mg} / \mathrm{ml}$ damages the membranes of mitochondria and endoplasmic reticulum that is evidenced by both the change in their ultrastructure and the release of marker enzymes in the supernatant [16]. Thus, it is very important to choose digitonin concentration at which plasmalemmas of all cells would be permeabilized, while organelle membranes remain intact.

It should be noted that for the complete selective plasma membrane hepatocytes permeabilization, researchers use digitonin in a very wide range of concentrations. Thus, according to Holmuhamedov E. L., this detergent is able to completely permeabilize liver cells already at concentration of $10 \mu \mathrm{g} / \mathrm{ml}$, and at $100 \mu \mathrm{g} / \mathrm{ml}$ to cause the release of cytochrome $C$ in the supernatant i.e. to damage mitochondrial membrane [7]. Other researchers have shown that digitonin at concentration of $10 \mu \mathrm{g} / \mathrm{ml}$ does not affect the integrity of the plasma membrane of hepatocytes and damages it at concentrations of
50-150 $\mu \mathrm{g} / \mathrm{ml}$ without changing mitochondria state $[15,17]$. In our test experiments a lot of attention was given to the selection of exact minimal digitonin concentration for complete hepatocyte permeabilization. In some cases, digitonin concentration of $20 \mu \mathrm{g} / \mathrm{ml}$ was sufficient, while in others $-100 \mu \mathrm{g} / \mathrm{ml}$. The cell number in suspension was the only parameter that changed during the experiments. Therefore, it was assumed that the degree of hepatocyte permeabilization depends rather on the ratio detergent amount/cell number than on digitonin concentration.

The aim of this work was to investigate the dependence of hepatocytes permeabilization degree on the ratio digitonin concentration/the cell number in suspension, and assess the mitochondrial oxidation state under different conditions of detergent application that would enable to adapt this technique for the study of mitochondrial respiration in situ.

\section{Materials and Methods}

Mature male underbred rats weighing 200$250 \mathrm{~g}$ were used for the study. Hepatocytes were isolated by the two-step Seglen method [18]. Cells were counted using hemocytometer. To assess the plasmalemma integrity, hepatocytes were stained with $0.1 \%$ trypan blue solution, and then examined using fluorescent or light microscopy (Nikon Optiphot-2) at an emission wavelength $>600 \mathrm{~nm}$ and an excitation wavelength $<560 \mathrm{~nm}$. Immediately after isolation, $75-90 \%$ of cells in the suspension were with intact plasma membranes (Fig. 1, A). Permeabilization was performed using digitonin in the intracellular solution for $10 \mathrm{~min}$ at $37^{\circ} \mathrm{C}$. Thereafter, hepatocytes were washed three times with the same solution, centrifuged each time at $50 \mathrm{~g}$, and plasma membrane integrity was determined (Fig. 1, C, D).

To assess the ability of hepatocyte mitochondria to maintain membrane potential, the fluorescence of rhodamine 123, the potential-sensitive dye ( $1 \mathrm{nM}$, pre-incubation for $10 \mathrm{~min}$ ), in the range of emission wavelengths $>560 \mathrm{~nm}$ at excitation by light with wavelength $485 \mathrm{~nm}$ was measured. The fluorescence of rhodamine 123 in permeabilized hepatocytes indicates the functional activity of mitochondria (the ability to maintain membrane potential) and intactness of the inner membranes (Fig. 1, $B$ ).

The oxygen uptake rate was measured using polarographic method, which is based on the recording of the electrochemical reduction of dissolved oxygen at the cathode at the potential difference of 0.6-0.7 V: 

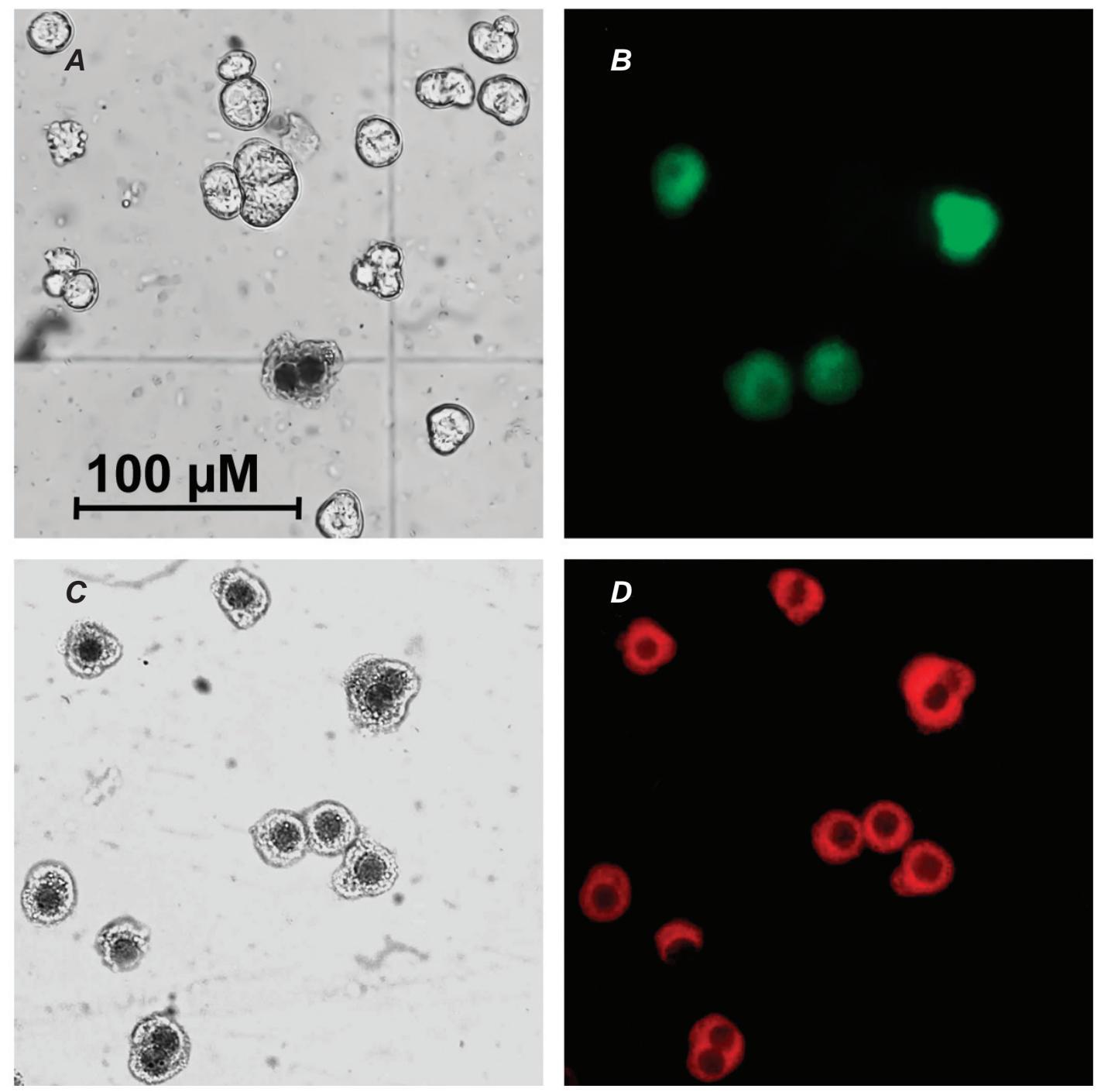

Fig. 1. Images of the isolated hepatocytes: A, C-intact and digitonin-permeabilized cells stained by trypan blue, in passing visible light; $B$ - fluorescence of permeabilized cells treated with rhodamine $123, \lambda_{\text {exc }}=485 \mathrm{~nm}$; $D$-fluorescence of permeabilized hepatocytes stained by trypan blue, $\lambda_{\text {exc }}=560 \mathrm{~nm}$; [digitonin] $=20 \mu \mathrm{g} / \mathrm{ml}$ per $1 \times 10^{6}$ cells; [rhodamine 123] = $1 \mathrm{nM}$; [trypan blue] $=0.1 \%$; images were obtained using fluorescent microscope Nikon Optiphot-2 with integrated camera

$$
\begin{aligned}
& \mathrm{O}_{2}+2 \mathrm{H}^{+}+2 \mathrm{e}^{-}=\mathrm{H}_{2} \mathrm{O}_{2}, \\
& \mathrm{H}_{2} \mathrm{O}_{2}+2 \mathrm{H}_{+}+2 \mathrm{e}^{-}=2 \mathrm{H}_{2} \mathrm{O} .
\end{aligned}
$$

Diffusion current was determined using polarographic system which consisted of: Clark oxygen electrode, unit “Oxygen monitor YSI 5300”, potentiometer KSP-4, magnetic stirrer for suspension and glass thermostated closed chamber (volume of $1.6 \mathrm{ml}$ ). Oxygen uptake by permeabilized hepatocytes was studied by oxidation of endogenous substrates, $\alpha$-ketoglutarate $(1 \mathrm{mM})$ and succinate $(0.35 \mathrm{mM})$ at $37^{\circ} \mathrm{C}$. Respiration was stimulated by adding $1.2 \mu \mathrm{M}$ ADP (concentration in polarographic chamber was increased to $750 \mu \mathrm{M}$ ).
The basic extracellular solution had the following composition, $\mathrm{mM}$ : $\mathrm{NaCl}-140.0, \mathrm{KCl}-$ 4.7, $\mathrm{CaCl}_{2}-1.3, \mathrm{MgCl}_{2}-1.0$, HEPES - 10.0, glucose - 5.0; $\mathrm{pH}$ 7.4. At certain stages of isolation of liver cells, the following modified solutions were used: 1) without addition $\mathrm{CaCl}_{2}$ and with $1 \mathrm{mM}$ EGTA; 2) supplemented with collagenase (120 unit/ $\mathrm{ml})$ and $\mathrm{CaCl}_{2}(3 \mathrm{mM})$. Intracellular solution had the following composition, $\mathrm{mM}: \mathrm{KCl}-90.0, \mathrm{NaCl}-$ 15.0, $\mathrm{KH}_{2} \mathrm{PO}_{4}-2.0, \mathrm{MgCl}_{2}-1.0$, HEPES - 10.0, EGTA - 0.5; $\mathrm{pH}$ 7.2. The solution composition corresponded to the ion composition of the hepatocytes intracellular medium [19-21]. Statistical processing 
of the obtained data was performed using the software Microsoft Office Excel.

\section{Results and Discussion}

To determine the dependence of the degree of permeabilization on the ratio digitonin concentration/ the number of hepatocytes in suspension, both parameters were changed. That is, digitonin, at final concentrations of $10,25,50$ and $100 \mu \mathrm{g} / \mathrm{ml}$, was added to the suspensions with varying amount of hepatocytes. The experimental data were divided into three groups according to the number of cells in suspension. The samples of group I contained from 0.9 to 1.7 million cells $/ \mathrm{ml}$ of suspension (on the average $1.27 \pm 0.09$ million cells $/ \mathrm{ml}$ ), samples of group II contained 2.0-3.0 million cells $/ \mathrm{ml}$ (2.45 \pm 0.11 million cells $/ \mathrm{ml})$ and samples of group III contained 4.0-5.6 million cells/ml (4.67 \pm 0.46 million cells $/ \mathrm{ml}$ ).

In isolated hepatocytes (control) $21.67 \pm 2.94 \%$ of cells were colored by trypan blue. In group I, complete permeabilization of plasma membrane was observed already at digitonin concentration of $25 \mu \mathrm{g} / \mathrm{ml}$, in group II - at $50 \mu \mathrm{g} / \mathrm{ml}$, while in
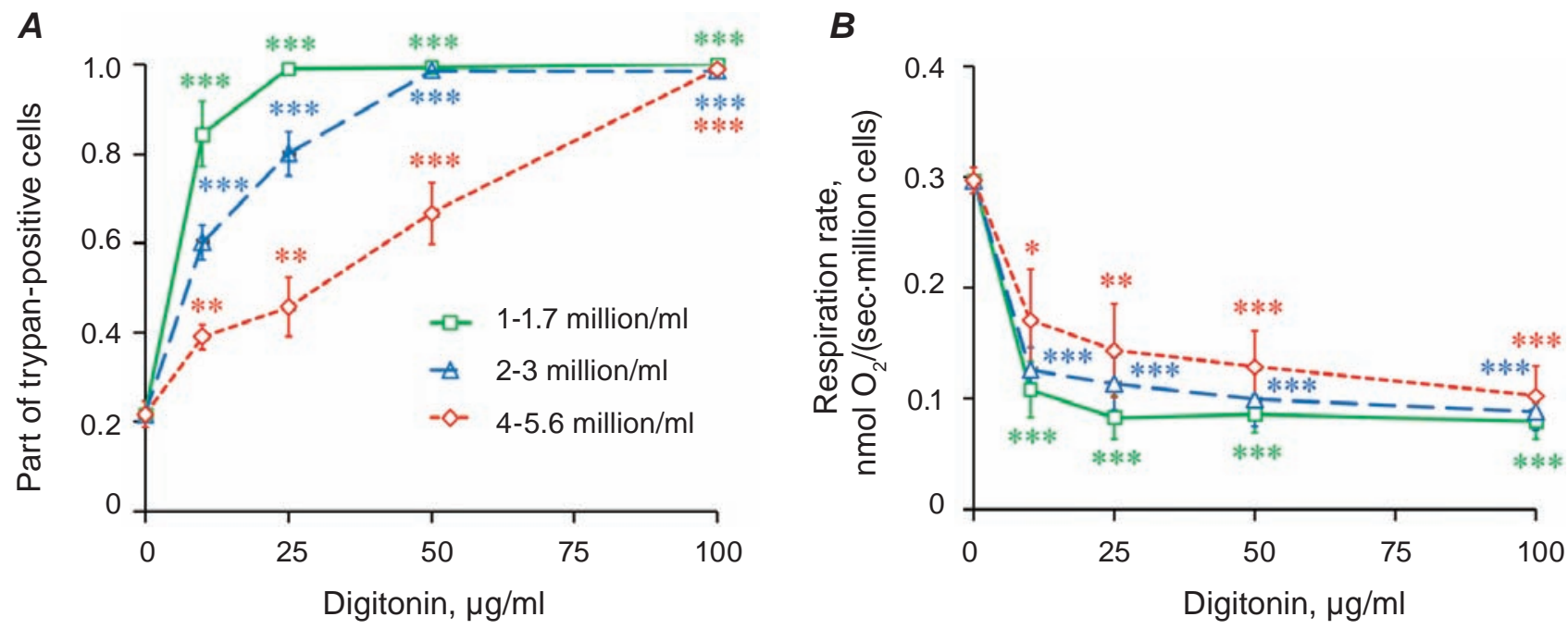

C

$D$

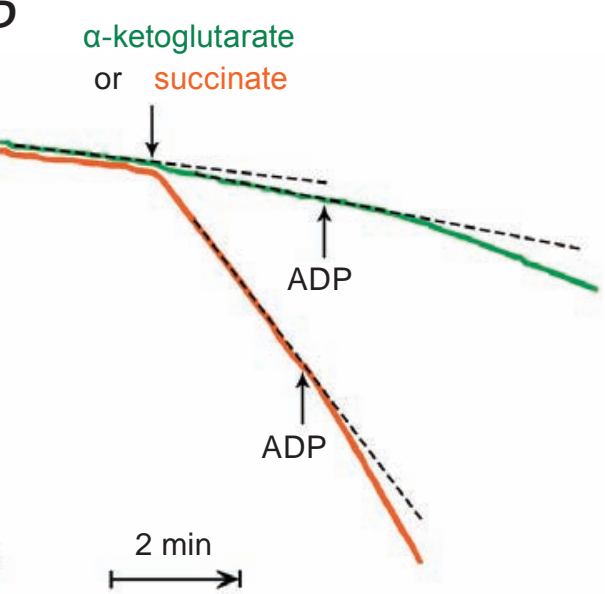

Fig. 2. Part of trypan-positive cells and respiration rate of hepatocytes in the presence of digitonin: A-degree of permeabilization at various digitonin concentrations and cell suspension densities; $B$ - rate of endogenous respiration of permeabilized hepatocytes; $C$ and $D$ - polarographic records of oxygen tension changes in suspension of intact and permeabilized hepatocytes upon the oxidation of endogenous substrates and exogenous $\alpha$-ketoglutarate (green line) or succinate (orange line); vertical arrows indicate the time of the addition of oxidation substrates or ADP; [succinate] $=0.35 \mathrm{mM},[\alpha$-ketoglutarate $]=1 \mathrm{mM},[\mathrm{ADP}]=750 \mu \mathrm{M}$; hereinafter: * statistical significance relative to control $(P \leq 0.05)$; ** statistical significance relative to control $(P \leq 0.01)$; *** statistical significance relative to control $(P \leq 0.001) ;(n=3-5)$ 
group III - only at concentration of $100 \mu \mathrm{g} / \mathrm{ml}$ (Fig. 2, A). Addition of lower concentrations of the detergent caused membrane permeabilization only in part of hepatocytes of all three groups.

The degree of permeabilization was also evaluated based on the rate of endogenous respiration and respiration stimulated by oxidation substrates and ADP. It is known that the low level of endogenous respiration is inherent in the cells with damaged plasma membrane [10]. It is caused by the decrease in the concentration of substrates in cytoplasm due to their diffusion in extracellular medium. Treatment of isolated hepatocytes with digitonin led to a decrease in the rate of oxygen uptake by hepatocytes at the oxidation of endogenous substrates. In
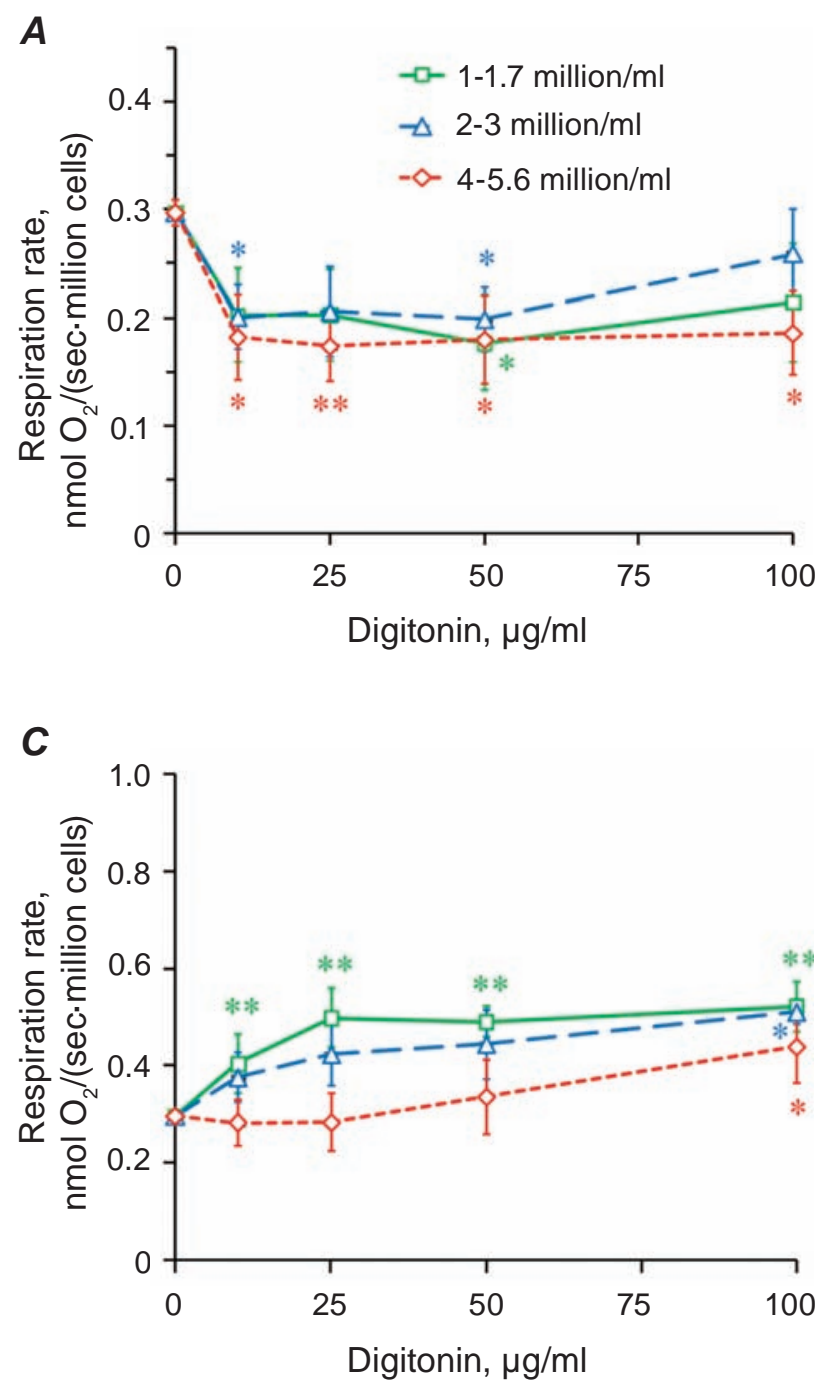

group I the endogenous respiration rate reached its minimum at digitonin concentration of $25 \mu \mathrm{g} / \mathrm{ml}$, in group II - at concentration of $50 \mu \mathrm{g} / \mathrm{ml}$, while in group III - only at concentration of $100 \mu \mathrm{g} / \mathrm{ml}$ (Fig. 2, B). These data are entirely consistent with the results of the Trypan Blue assay.

The addition of $\alpha$-ketoglutarate and succinate to the polarographic chamber with intact hepatocytes almost did not affect oxygen uptake rate (Fig. 2, C), in contrast to the permeabilized cells (Fig. 2, $D$ ). The addition of $\alpha$-ketoglutarate to permeabilized hepatocytes maintained respiration indicators at a stable level, slightly higher than the level of endogenous respiration at the corresponding digitonin concentration, but lower than in intact cells (Fig. 3, A). The rate
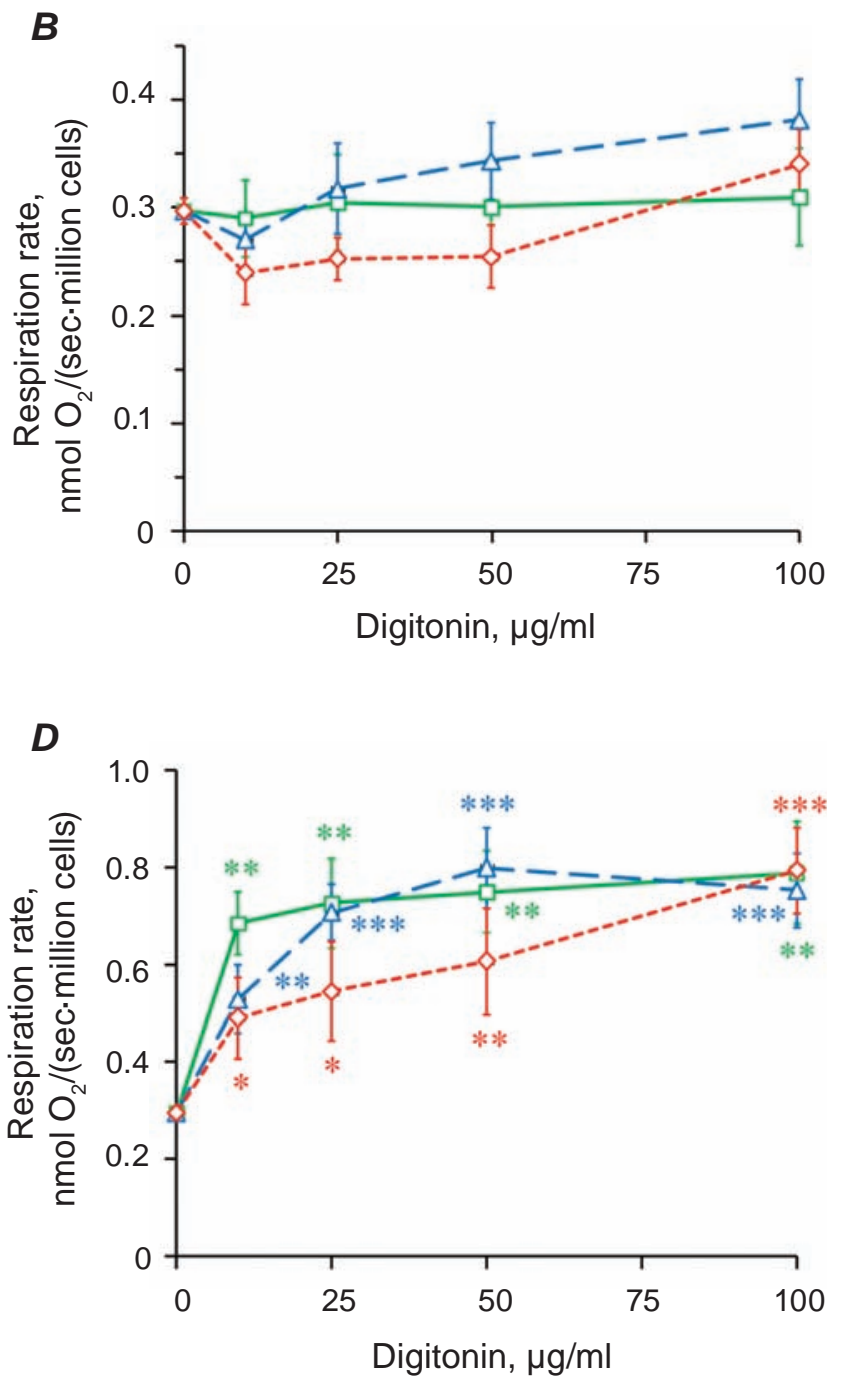

Fig. 3. Dependence of respiration rate of permeabilized hepatocytes upon oxidation of exogenous substrates (A and $C$; metabolic condition close to the state $S_{4}$ ) and activation of oxidative phosphorylation by ADP (B and $D$; state $S_{3}$ ) on digitonin concentration: $A$ and $B$-at oxidation of $\alpha$-ketoglutarate; $C$ and $D$-at oxidation of succinate; $[\alpha$-ketoglutarate $]=1 \mathrm{mM}$, [succinate $]=0.35 \mathrm{mM},[A D P]=750 \mu \mathrm{M}$ 
of the oxygen uptake by permeabilized hepatocytes in the simultaneous presence of $\alpha$-ketoglutarate and ADP in the polarographic chamber increased to the level of endogenous respiration of intact cells (Fig. 3, $B)$. That is, the introduction of $\alpha$-ketoglutarate in the presence of ADP restored oxidative processes in permeabilized hepatocytes. It is known that respiration in intact cells occurs mainly due to oxidation of NAD-dependent substrates. Thus, restoration of oxygen consumption by $\alpha$-ketoglutarate to the level of intact hepatocytes evidences that digitonin does not affect the functioning of NAD-dependent components of the mitochondrial respiratory chain.

Adding succinate to the chamber significantly intensified oxygen uptake by permeabilized hepatocytes (Fig. 3, $C$ ), the rate of which increased even more with the addition of ADP and exceeded the level of endogenous respiration of intact cells (Fig. 3, $D)$. This is consistent with the concept of the priority of the application of succinate compared to other substrates and its ability to monopolize the respiratory chain [22], providing a high level of intensity of mitochondrial processes in accordance with the cell needs. The dependence of the rate of ADP-stimulated respiration upon succinate oxidation on the digitonin concentration and the number of cells correlates well with the results of the Trypan Blue assay: the intensity of oxygen uptake in group I reached the peak at digitonin final concentration of $25 \mu \mathrm{g} /$ $\mathrm{ml}$, in group II - at final concentration of $50 \mu \mathrm{g} / \mathrm{ml}$, in group III - at final concentration of $100 \mu \mathrm{g} / \mathrm{ml}$ (Fig. 3, D).

Taking this into account, the analysis of the obtained results allows suggesting that the ratio between the amount of digitonin and the number of cells in suspension is the determining factor in the study of mitochondrial respiration in situ. The optimal ratio of digitonin amount/amount of hepatocytes was found to be 20-22 $\mu \mathrm{g}$ per 1 million cells (Fig. 4, $B)$. The dependence of the amount of trypan-positive hepatocytes on the ratio of the amount of digitonin to the number of liver cells in suspension has been shown in Fig. 4, A. As it can be seen, 20-22 $\mu$ g of digitonin per 1 million cells has been also sufficient for complete hepatocytes permeabilization. That is, the results of Trypan Blue assay are fully consistent with the results obtained during the study of respiration processes.

Respiratory control by Chance (the ratio of the oxygen uptake rate in the state $S_{3}$ to the oxygen uptake rate in the state $S_{4}$ ), which characterizes the coupling of respiration processes and oxidative phosphorylation, reached the maximum at a ratio of digitonin concentration to the number of cells of about 20-22 $\mu$ g per 1 million cells. In particular, the dependence of the respiratory control on the ratio of digitonin concentration/the number of hepatocytes upon $\alpha$-ketoglutarate oxidation had a bell-like shape curve with a maximum value in the range stated above. This feature, upon the succinate oxidation
$\boldsymbol{A}$

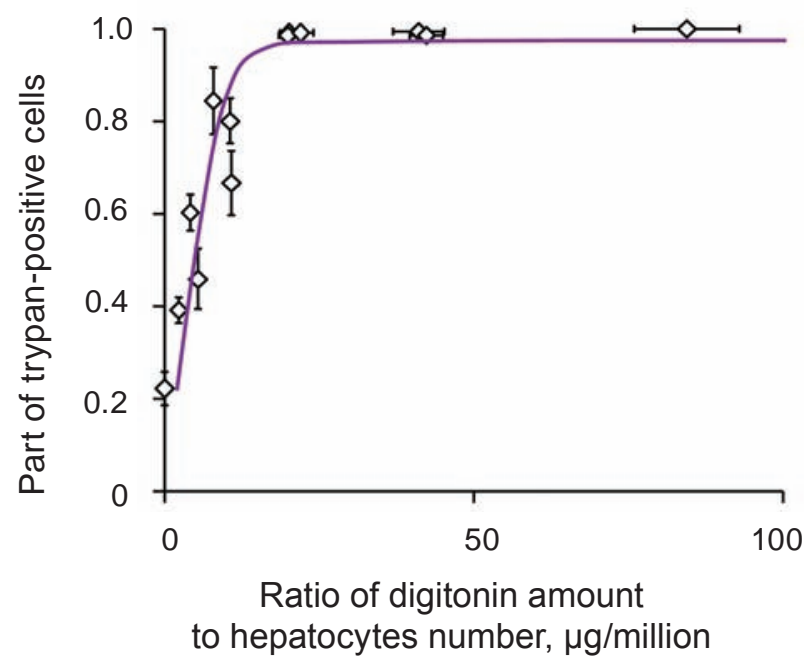

$D$

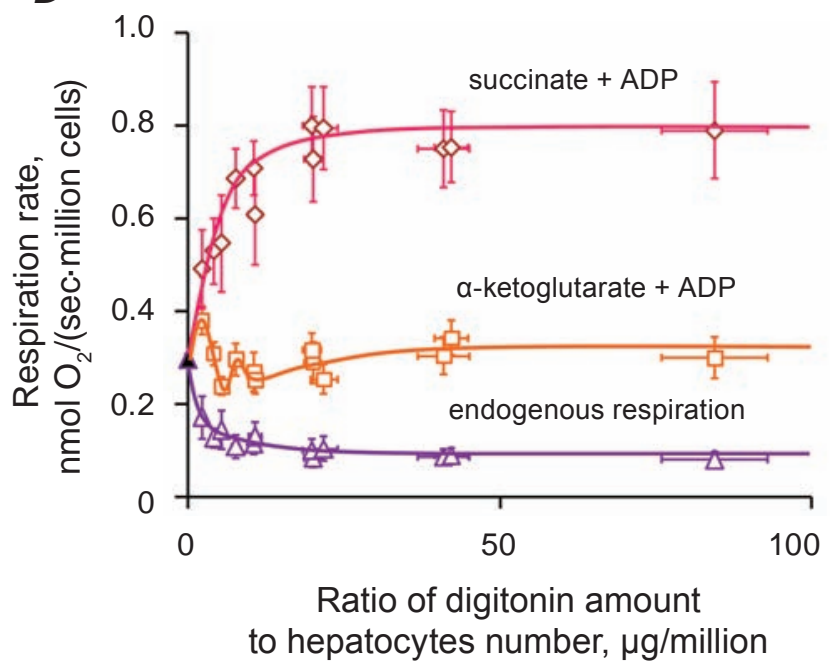

Fig. 4. Degree of hepatocyte plasma membrane permeabilization (A) and respiration rate of permeabilized hepatocytes (B) upon different ratio of digitonin amount to cell number: initial experimental data are shown in Fig. 2 and 3 
and minimum value of the ratio of digitonin concentration/the number of cells, reached the highest value, however decreased dramatically at the ratio of more than $21.8 \mu \mathrm{g}$ digitonin per one million hepatocytes.

The increase in the ratio of the digitonin concentration to the number of cells caused the decrease in the respiratory control index upon both $\alpha$-ketoglutarate and succinate oxidations. This occurs owing to the decrease in intensity of oxygen consumption in state $S_{3}$ and/or the increase in oxygen consumption in state $S_{4}$, although the alterations in respiration rates themselves are insignificant within the range of statistical error. The increase in oxygen uptake rate in state $S_{4}$ upon the decrease in respiratory control indicates the need to compensate for the proton leak across the mitochondria plasma membrane due to alterations in its permeability.

Thus, the density of the hepatocytes suspension significantly affects the degree of plasma membrane permeabilization by digitonin: a higher concentration of digitonin is required for the larger amount of cells.

The low ratio of digitonin concentration to the number of cells does not provide complete hepatocytes permeabilization and does not enable complete penetration of exogenous substrates. At the high ratio of the digitonin concentration to the number of cells, the integrity of not only the plasma membrane is disrupted but also the membrane of intracellular organelles that negatively affects the functioning of hepatocytes and prevents their application as a model.

It is obvious that the optimal ratio of the digitonin concentration to the number of cells in suspension will be different for various tissues. For adequate selection of the ratio it is necessary not only to assess plasma membrane integrity (Trypan Blue assay, determination of the release of cytoplasm marker proteins) but also to evaluate organelle functional activity. Without performing such tests, not only objective comparison of the results from different authors, but also obtaining high quality preparations of permeabilized cells and minimizing effects of artifacts are not possible.

\section{ЕКСПЕРИМЕНТАЛЬНЕ ОБГРУНТУВАННЯ МОДЕЛІ ПЕРМЕАБІЛІЗОВАНИХ ГЕПАТОЦИТІВ ДЛЯ ДОСЛІДЖЕННЯ ДИХАННЯ МІТОХОНДРІЙ IN SITU}

\author{
В. М. Мерлавський, Б. О. Манько, \\ О. В. Іккерт, В. В. Манько \\ Львівський національний університет \\ імені Івана Франка, Україна \\ e-mail: vvmanko@lnu.edu.ua
}

Для експериментального обгрунтування моделі пермеабілізованих гепатоцитів щурів оцінювали ступінь пермеабілізації клітин, використовуючи трипановий тест та їхню швидкість дихання, яку визначали полярографічним методом за окислення ендогенних субстратів - сукцинату $(0,35$ мM) та $\alpha$-кетоглутарату (1 мM). Окисне фосфорилювання стимулювали ADP (750 мкM). Ступінь пермеабілізації гепатоцитів дигітоніном залежить як від його концентрації у середовищі, так і кількості клітин у суспензії. За 0,9-1,7 млн. клітин в одному мл суспензії повна пермеабілізація відбувалась за концентрації 25 мкг/мл дигітоніну, за 2,0-3,0 млн. клітин 50 мкг/мл дигітоніну, а за 4,0-5,6 млн. клітин 100 мкг/мл дигітоніну. Отже, чим більша густина суспензії клітин, тим більшою має бути концентрація дигітоніну. Обробка гепатоцитів дигітоніном знижувала швидкість ендогенного дихання, яка досягала мінімуму теж за 20-22 мкг дигітоніну на один млн. клітин. Додавання до пермеабілізованих гепатоцитів $\alpha$-кетоглутарату підтримувало показники дихання на стабільному рівні, вищому за рівень ендогенного дихання за відповідної концентрації дигітоніну, але не інтактних клітин. За одночасного внесення $\alpha$-кетоглутарату й ADP швидкість дихання пермеабілізованих гепатоцитів збільшувалась до рівня ендогенного дихання інтактних клітин незалежно від концентрації дигітоніну. Внесення у комірку лише сукцинату та особливо сукцинату за наявності ADP значно активувало дихання пермеабілізованих гепатоцитів, яке перевищувало рівень ендогенного дихання 
інтактних клітин. Залежність швидкості сукцинатстимульованого дихання від концентрації дигітоніну досягала максимуму за 20-22 мкг дигітоніну у розрахунку на один млн. клітин. Передбачається, що оптимальне співвідношення між кількістю дигітоніну і кількістю клітин у суспензії для різних тканин відрізняється.

К л юч о в і с ло ва: гепатоцити пермеабілізовані, дигітонін, мітохондрії, дихання, сукцинат, $\alpha$-кетоглутарат.

\section{ЭКСПЕРИМЕНТАЛЬНОЕ ОБОСНОВАНИЕ МОДЕЛИ ПЕРМЕАБИЛИЗИРОВАННЫХ ГЕПАТОЦИТОВ ДЛЯ ИССЛЕДОВАНИЯ ДЫХАНИЯ МИТОХОНДРИЙ IN SITU}

\section{В. М. Мерлавский, Б. А. Манько, \\ О. В. Иккерт, В. В. Манько}

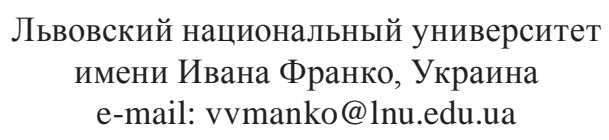

Для экспериментального обоснования модели пермеабилизированных гепатоцитов крыс оценивали степень пермеабилизации клеток, используя трипановый тест, и их скорость дыхания, которую определяли полярографическим способом при окислении эндогенных субстратов - сукцината $(0,35 \mathrm{MM})$ и $\alpha$-кетоглутарата $(1 \mathrm{MM})$. Окислительное фосфорилирование стимулировали ADP (750 мкM). Степень пермеабилизации гепатоцитов дигитонином зависит как от его концентрации в среде, так и количества клеток в суспензии. При 0,9-1,7 млн. клеток в 1 мл суспензии полная пермеабилизация осуществлялась при концентрации 25 мкг/мл дигитонина, при 2,0-3,0 млн. клеток - 50 мкг/мл дигитонина, а при 4,0-5,6 млн. клеток - 100 мкг/мл дигитонина. Следовательно, чем большая плотность суспензии клеток, тем большей должна быть концентрация дигитонина. Обработка гепатоцитов дигитонином снижала скорость эндогенного дыхания, которое достигало минимума при 20-22 мкг дигитонина на один млн. клеток. Внесение к пермеабилизированным гепатоцитам $\alpha$-кетоглутарата поддерживало показатели дыхания на стабильном уровне, высше уровня эндогенного дыхания при соответствующей концентрации дигитонина, но не интактных клеток.
При одновременном внесении $\alpha$-кетоглутарата и ADP скорость дыхания пермеабилизированных гепатоцитов увеличивалась до уровня эндогенного дыхания интактных клеток независимо от концентрации дигитонина. Внесение в ячейку только сукцината и особенно сукцината при наличии ADP существенно активировало дыхание пермеабилизированных гепатоцитов, которое превышало уровень эндогенного дыхания интактных клеток. Зависимость скорости сукцинатстимулированного дыхания от концентрации дигитонина достигала максимума при 20-22 мкг дигитонина в расчете на один млн. клеток. Предполагается, что оптимальное соотношение между количеством дигитонина и количеством клеток в суспензии для различных тканей отличается.

К л ю че в ы е с л о в а: гепатоциты пермеабилизированные, дигитонин, митохондрии, дыхание, сукцинат, $\alpha$-кетоглутарат.

\section{References}

1. Chance B., Williams G. R. Respiratory enzymes in oxidative phosphorylation. I. Kinetics of oxygen utilization. J. Biol. Chem. 1955; 217(1): 383-393.

2. Dolman N. J., Gerasimenko J. V., Gerasimenko O. V., Voronina S. G., Petersen O. H., Tepikin A. V. Stable Golgi-mitochondria complexes and formation of Golgi $\mathrm{Ca}^{2+}$ gradients in pancreatic acinar cells. J. Biol. Chem. 2005; 280(16): 15794-15799.

3. Rizzuto R., Pozzan T. Microdomains of intracellular $\mathrm{Ca}^{2+}$ : molecular determinants and functional consequences. J. Physiol. Rev. 2006; 86(1): 369-408.

4. Manko V. V. $\mathrm{Ca}^{2+}$-functional units conception concerning to secretory cell of Chironomus plumosus larvae salivary gland. Studia Biologica. 2008; 2(1): 33-50. (In Ukrainian).

5. Saks V. A., Dos Santos P., Gellerich F. N., Diolez P. Quantitative studies of enzymesubstrate compartmentation, functional coupling and metabolic channeling in muscle cells. Mol. Cell. Biochem. 1998; 184(1-2): 291-307.

6. Park S. Y., Gifford J. R., Andtbacka R. H., Trinity J. D., Hyngstrom J. R., Garten R. S., Diakos N. A., Ives S. J., Dela F., Larsen S., Drakos S., Richardson R. S. Cardiac, skeletal, and smooth muscle mitochondrial respiration: are all mitochondria created equal? Am. J. 
Physiol. Heart Circ. Physiol. 2014; 307(3): 346352.

7. Holmuhamedov E., Lemasters J. J. Ethanol exposure decreases mitochondrial outer membrane permeability in cultured rat hepatocytes. Arch. Biochem. Biophys. 2009; 481(2): 226-233.

8. Manko B., Klevets M., Manko V. An implication of novel methodology to study pancreatic acinar mitochondria under "in situ" conditions. Cell Biochem. Funct. 2013; 31(2): 115-121.

9. Shlykov S. G., Babich L. G., Kosterin S. A. Suspension of smooth-muscle cells treated with digitonin solution as a model for studying the myometrial endoplasmic-reticulum calcium pump. Biochemistry (Mosc.). 1997; 62(12): 16661671. (In Russian).

10. Hulak P. V., Dudchenko A. M., Zaytsev V. V. et al. Hepatocyte: functional-metabolic properties. M.: Nauka, 1985. 272 p. (In Russian).

11. Hems R., Stubbs M., Krebs H. A. Restricted permeability of rat liver for glutamate and succinate. Biochem. J. 1968; 107(6): 807-815.

12. Manko B. O., Manko V. V. Influence of $\mathrm{Ca}^{2+}$ on kinetic parameters of pancreatic acinar mitochondria in situ respiration. Ukr. Biokhim. Zhurn. 2013; 85(4): 48-60. (In Ukrainian).

13. Nishikawa M., Nojima S., Akiyama T., Sankawa U., Inoue K. Interaction of digitonin and its analogs with membrane cholesterol. J. Biochem. 1984; 96(4): 1231-1239.

14. Colbeau A., Nachbaur J., Vignais P.M. Enzymic characterisation and lipid composition of rat liver subcellular membranes. Biochim. Biophys. Acta. 1971; 249(2): 462-492.

15. Fiskum G., Craig S. W., Decker G. L., Lehninger A. L. The cytoskeleton of digitonintreated rat hepatocytes. PNAS. 1980; 77(6): 3430-3434.
16. Cook G. A., Gattone V. H., Evan A. P., Harris R. A. Structural changes of isolated hepatocytes during treatment with digitonin. Biochim. Biophys. Acta. 1983; 763(4): 356-367.

17. Meredith M. J., Reed D. J. Status of the mitochondrial pool of glutathione in the isolated hepatocyte. J. Biol. Chem. 1982; 257(7): 37473753.

18. Seglen P. O. Preparation of isolated rat liver cells. Methods Cell Biol. 1976; 13: 29-83.

19. Gasbarrini A., Borle A. B., Farghali H., Bender C., Francavilla A., Van Thiel D. Effect of anoxia on intracellular ATP, $\mathrm{Na}^{+}, \mathrm{Ca}^{2+}, \mathrm{Mg}^{2+}$, and cytotoxicity in rat hepatocytes. J. Biol. Chem. 1992; 267(10): 6654-6663.

20. Tanaka A., Chance B., Quistorff B. A Possible role of inorganic phosphate as a regulator of oxidative phosphorylation in combined urea synthesis and gluconeogenesis in perfused rat liver. J. Biol. Chem. 1989; 264(17): 10034-10040.

21. Wang K., Wondergem R. Hepatocyte water volume and potassium activity during hypotonic stress. J. Membr. Biol. 1993; 135(2): 137-144.

22. Zakharchenko M. V., Zakharchenko A. V., Khunderyakova N. V., Tutukina M. N., Simonova M. A., Vasilieva A. A., Romanova O. I., Fedotcheva N. I., Litvinova E. G., Maevsky E. I., Zinchenko V.P., Berezhnov A. V., Morgunov I. G., Gulayev A. A., Kondrashova M. N. Burst of succinate dehydrogenase and $\alpha$-ketoglutarate dehydrogenase activity in concert with the expression of genes coding for respiratory chain proteins underlies short-term beneficial physiological stress in mitochondria. Int. J. Biochem. Cell Biol. 2013; 45(1): 190-200.

Received 14.07.2015 